References

Barber, A. A., and Bernheim, F. (1967). Advances in Gerontological Research, 2,355 .

Begg, T. B., and Hearns, J. B. (1966). Clinical Science, 31, 87.

Bulletin of the World Health Organization, 1970, 43, 891.

Colley, J., and Dormandy, J. A. (1973). To be published

Dangerfield, W. G. (1971). Proceedings of the Royal Society of Medicine, 64,896 .

Dormandy, J. A. (1970). Annals of the Royal College of Surgeons, 47, 211.

Dormandy, J. A. (1971 a). British Medical fournal, 4, 716.

Dormandy, J. A. (1973). British fournal of Surgery, 60, 187

Dormandy, J. A., Kenefick, J., and Hoare, E. (1972). In Blood Flow Measurement, ed. C. Roberts. London, Sector Publishing Ltd.

Dormandy, T. L. (1969). Lancet, 2, 684.

Dormandy, T. L. (1971 b). British fournal of Haematology, 20, 457.

Fredrickson, D. S., Levi, R. I., and Lees, R. S. (1967). New England fournal of Medicine, 276, 34, 94, 148 .

Greenhalgh, R. M., et al. (1971). Lancet, 2, 947.

Greenhalgh, R. M., et al. (1971). Lancet, 2, 947.

Gutteridge, J. M. C., and Dormandy, T. L. (1973).

Harman, D. (1956). Fournal of Gerontology, 11, 298. British fournal of Surgery, 59, 418.
.

Mackintosh, C. E., Dormandy, J. A., and Waite, D. H. (1973). Lancet, 1, 1477.
McLellan, G. H. (1971). Clinical Chemistry, 17, 535.

Merrill, E. W. (1969). Physiological Reviews, $49,863$.

Millar, H. K., Simpson, J. G., and Staller, A. L. (1971). Fournal of Clinical Pathology, 24, 827.

Newall R G. (1971). Clinica Chimica Acta, 32, 185.

Noble, R. P., and Campbell, F. M. (1970). Clinica Chimica Acta, 16, 166.

Poiseuille, J. L. M. (1846). Comptes Rendus Hebdomadaires des Séances de l'Academie des Sciences, 9, 433.

Rosenblum, W. I. (1969). Nature, 221, 365

Slater, T. (1972). Free Radical Mechanisms in Tissue Injury. London, Pion. Stirland, R. M. (1956). Lancet, 1, 672.

Stocks, J. (1972). Autoxidation of Human Red Blood Cells. M.Sc. Thesis, London University.

Stocks, J., and Dormandy, T. L. (1971). British fournal of Haematology,

Stocks, J., Offerman, E. L., Modell, C. B., and Dormandy, T. L. (1972) British fournal of Haematology, 23, 713 .

Stone, M. C., and Thorpe, J. M. (1966). Clinica Chimica Acta, 14, 812

Stone, M. C., Thorpe, J. M., Mills, G. L., and Dick, T. B. S. (1970) Clinica Chimica Acta, 30, 809.

Stone, M. C., Thorpe, J. M., Mills, G. L., and Dick, T. B. S. (1971). Clinica Chimica Acta, 31, 333.

Weaver, J. P. A., Evans, A., and Walder, D. N. (1969). Clinical Science, 36, 1. Woodman, D. D., and Price, C. P. (1972). Clinica Chimica Acta, 38, 39.

\title{
Prognostic Significance of Rheological and Biochemical Findings in Patients with Intermittent Claudication
}

\section{J. A. DORMANDY, \\ E. HOARE, \\ A. H. KHATTAB,}

British Medical fournal, 1973, 4, 581-583

\section{Summary}

To assess the prognostic significance of clinical and laboratory findings in intermittent claudication a group of 62 untreated patients was followed up in detail for periods of from one to three years. There was a significant correlation between progressive deterioration of the peripheral circulatory disturbance and the initial blood viscosity, the plasma fibrinogen level, and the susceptibility of red cell lipids to autoxidation.

\section{Introduction}

We recently reviewed the clinical, haemodynamic, rheological, and biochemical findings in 126 patients with intermittent claudication (Dormandy et al., 1973). Sixty-two of these patients have now been followed up for periods of from one to three years. During this time all were assessed clinically and had their baseline investigations repeated at regular intervals of one or two months. We here consider the prognostic significance of our initial findings in the light of the patients' subsequent progress.

\section{Patients}

Our series as a whole has been described in our previous paper. Of the 62 patients who are included in the present study none

\footnotetext{
Department of Surgery, Royal Free Hospital, London N.W.3, and Department of Applied Physiology, Royal College of Surgeons, London W.C.2

J. A. DORMANDY, F.R.c.s., Senior Registrar

E. HOARE, F.R.C.s., Registrar

Department of Chemical Pathology, Whittington Hospital, London N.19

A. H. KHATTAB, M.B., Senior Registrar

D. E. ARROWSMITH, F.I.M.L.T., Chief Technician

T. L. DORMANDY, M.R.c.PATH., F.R.C.S., Consultant Chemical Pathologist
}

\section{E. ARROWSMITH, T. L. DORMANDY}

had undergone reconstructive arterial surgery during the follow-up period or for a minimum of a year before their first visit. (Thirteen had had arterial surgery and five had had a lumbar sympathectomy at an earlier date.) The average age of the patients at the beginning of the follow-up was 64 years (range 46-85 years). Twenty-six patients had definite evidence of ischaemic heart disease, 21 had a blood pressure above $160 / 100 \mathrm{~mm} \mathrm{Hg}$, and three were well-controlled diabetics on oral hypoglycaemic drugs. There had been a history of intermittent claudication for an average of just over two years before their first visit. Seven of the patients died during the follow-up period, six of them known cases of ischaemic heart disease.

\section{Methods}

INVESTIGATIONS

Our methods and our interpretation of results have already been described (Dormandy et al., 1973). The patients' calf blood flow was measured at rest and after a standard exercise by using a mercury-in-rubber, strain-gauge plethysmograph. More recently the thigh blood flow was also measured simultaneously with a new technique of selective femoral vein occlusion (Colley and Dormandy, 1973). Whole-blood viscosity was measured at two shear rates, 23 and $230 \mathrm{sec}^{-1}$. The red cell volume was also determined and the corrected viscosity (based on a theoretical "standard" packed cell volume of $45 \%$ ) was calculated. Blood was collected at the same time for plasma fibrinogen estimation and for serum lipid and lipoprotein studies. The latter included measurements of serum cholesterol, total lipids, triglycerides, lipoprotein electrophoresis, and the nephelometric estimation of small, medium, and large particles (S. M. L. scoring). The susceptibility of the red blood cells to autoxidation was assessed by measuring the generation of malonyldialdehyde under standard oxidative stress (Dormandy, 1971 ; Stocks et al., 1972).

\section{ASSESSMENT OF PROGRESS}

We have already considered the difficulty in assessing objectively the severity of intermittent claudication, and similar difficulties arise when assessing progress over a period of time. The shorten- 
TABLE I-Prognostic Significance of Initial Viscosities

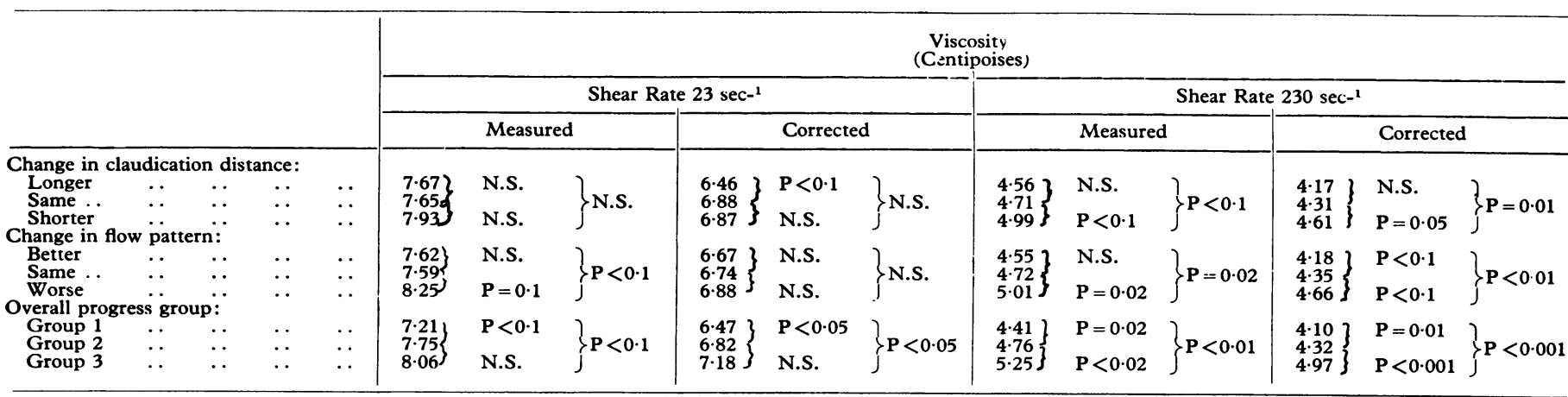

N.S. $=$ Not statistically significant.

The statistical significances refer to comparisons between the first with the second, the second with the third, and the first and the third groups.

ing or lengthening of the claudication distance is best expressed in terms of the initial distance rather than in absolute units. This can be related to other factors graphically on semilogarithmic scales (fig. 1). The appearance and disappearance of rest pain and changes in the peripheral pulses can be recorded. For more objective assessment the initial plethysmographic measurements can be repeated. In addition to considering these changes in isolation it was possible to divide our patients into three progress groups based on a combination of criteria. Patients in group 1 improved in every respect listed above. Patients in group 3 deteriorated in every respect. Patients in group 2 either did not change significantly in any respect or there was a conflict between the direction of the change in their symptoms, their pulses, and the objective flow measurements.

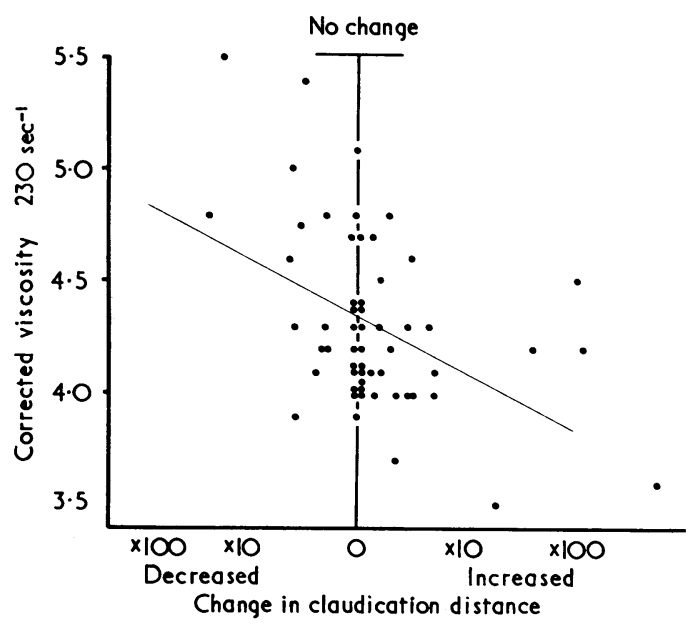

FIG. I-Correlation between changes in claudication distance over follow-up period and initial corrected viscosity $(\mathrm{r}=0.46 ; \mathrm{P}<0.01)$.

\section{Results}

\section{CLINICAL PROGRESS}

The claudication distance increased in 26 patients, remained unchanged in 21, and decreased in 14. Eighteen patients complained of rest pain initially. The symptom disappeared in seven of these, while in four it appeared for the first time during the follow-up period. In 18 patients there was a definite improvement in the peripheral pulses and in only six did we find that an arterial pulse which had been present previously disappeared. In none of the patients who died was death directly attributable to the peripheral vascular disease.

\section{FLOW MEASUREMENTS}

The peripheral blood flow pattern recorded by plethysmography improved significantly in 30 patients, 23 of whom also reported a significant lengthening of their claudication distance. In 11 patients the flow pattern deteriorated; and in eight of these the claudication distance also decreased. In 21 the flow remained unchanged.

\section{OVERALL PROGRESS}

On the basis outlined above 23 patients showed overall improvement (group 1), 31 patients did not show any significant or consistent change (group 2), and eight patients showed definite deterioration (group 3).

\section{PROGNOSTIC FEATURES}

Clinical.-The initial clinical state of the patients provided no prognostic clue to subsequent progress. The proportion of patients with an acute onset $(25 \%)$ was the same in all three prognostic groups. Of the three diabetic patients in the series the claudication improved in one, remained unchanged in one, and deteriorated in one. Complications which affect the outlook for life-for example, ischaemic heart disease and hypertension -had no adverse effect on the course of the disease in the legs.

Viscosity.-In addition to the increased blood viscosity in the series of patients as a whole (Dormandy et al., 1973) there was a significant inverse correlation between the initial blood viscosity and subsequent progress (figs. 1 and 2, table I). The correlation was most significant when progress was assessed by a combination of criteria; and it was more significant when viscosity was measured at a higher than at a lower shear rate. Viscosity was most significant as a prognostic index when measured at a shear rate of $230 \mathrm{sec}_{-}{ }^{1}$ and when corrected to a standard packed cell volume.

Plasma Fibrinogen.-A significant correlation was also found between the initial plasma fibrinogen levels and progress, whether the latter was assessed by serial blood flow measurements alone or by a combination of flow measurements and clinical changes (table II, fig. 2). In the patients who improved the mean initial plasma fibrinogen was within normal limits (less than $400 \mathrm{mg} / 100 \mathrm{ml}$ ), whereas in patients who deteriorated the mean initial plasma fibrinogen was almost double the mean normal.

Serum Lipids and Lipoproteins.-Neither the initial serum cholesterol nor the initial serum triglyceride levels bore any relation to subsequent progress (table III). The lipoprotein patterns classified both according to Fredrickson types (Fredrickson et al., 1967) and on the basis of nephelometric findings changed in $22 \%$ of the patients during follow-up; but 
TABLE II-Prognostic Significance of Initial Plasina Fibrinogen Concentrations

\begin{tabular}{|c|c|c|c|c|c|c|c|c|}
\hline \multicolumn{6}{|c|}{+} & \multicolumn{3}{|c|}{$\begin{array}{l}\text { Fibrinogen } \\
(\mathrm{mg} / 100 \mathrm{ml})\end{array}$} \\
\hline \multicolumn{6}{|c|}{ Change in claudication distance: } & \multirow{4}{*}{$\begin{array}{l}401 \\
417 \\
561\end{array}$} & \multirow{4}{*}{$\left.\begin{array}{l}\text { N.S. } \\
P<0.05\end{array}\right\}$} & \\
\hline Longer & .. & . & .. & . & . & & & \\
\hline Same & & . & . & . & $\ldots$ & & & $P<0.01$ \\
\hline \multirow{2}{*}{\multicolumn{6}{|c|}{ Change in flow pattern: }} & & & \\
\hline & & & & & & \multirow{3}{*}{$\begin{array}{l}382 \\
468 \\
543\end{array}$} & \multirow{3}{*}{$\left.\begin{array}{l}\mathrm{P}<0.05 \\
\text { N.S. }\end{array}\right\}$} & \\
\hline Same & $\therefore$ & $\ldots$ & $\because$ & $\because$ & $\because$ & & & $P<0.01$ \\
\hline Worse & & $\therefore$ & .. & . & . & & & \\
\hline \multicolumn{6}{|c|}{ Overall progress group: } & \multirow{4}{*}{$\begin{array}{l}398 \\
433 \\
605\end{array}$} & \multirow{4}{*}{\multicolumn{2}{|c|}{\}$P<0.001$}} \\
\hline Group 1 & . & & . & $\cdots$ & . & & & \\
\hline $\begin{array}{l}\text { Group } 2 \\
\text { Group } 3\end{array}$ & $\cdots$ & $\cdots$ & . & $\cdots$ & . & & & \\
\hline Group 3 & & & & & & & & \\
\hline
\end{tabular}

N.S. $=$ Not statistically significant.

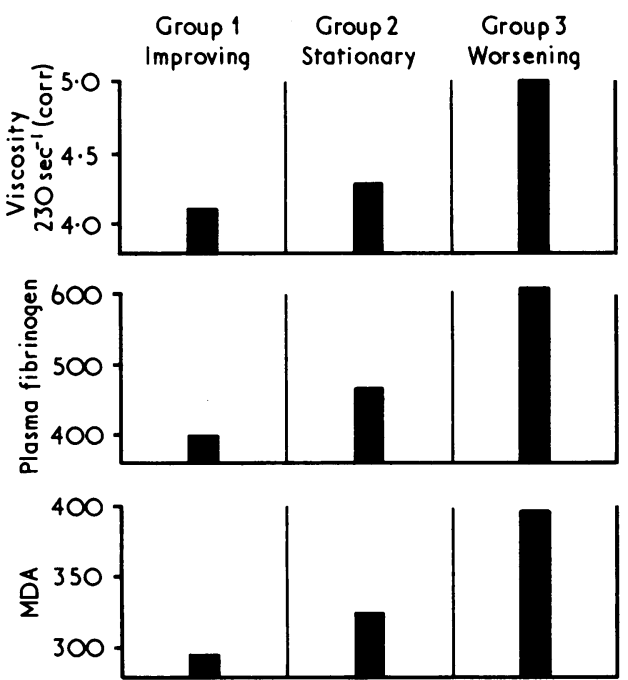

FIG. 2-Distribution of initial viscosities, plasma fibrinogen levels, and red cell malonyldialdehyde (MDA) values among the three progress groups. (Plasma fibrinogen in $\mathrm{mg} / 100 \mathrm{ml}$; $\mathrm{MDA}$ in $\mathrm{nmol} / \mathrm{g}$ haemoglobin; viscosity in centipoises.)

neither the initial pattern nor the changes were related to progress.

Red Cell Lipids. - The susceptibility of the red cell lipids to autoxidation (red cell malonyldialdehyde) increased with a worsening prognosis as assessed by any single criterion (table III). However, the correlation was statistically significant only when the mean malonyldialdehyde of the patients who showed overall improvement was compared with the mean malonyldialdehyde of patients who deteriorated (table III, fig. 2).

TABLE III-Prognostic Significance of Initial Serum Cholesterol, Serum Triglycerides, and Red Cell Malonyldialdehyde

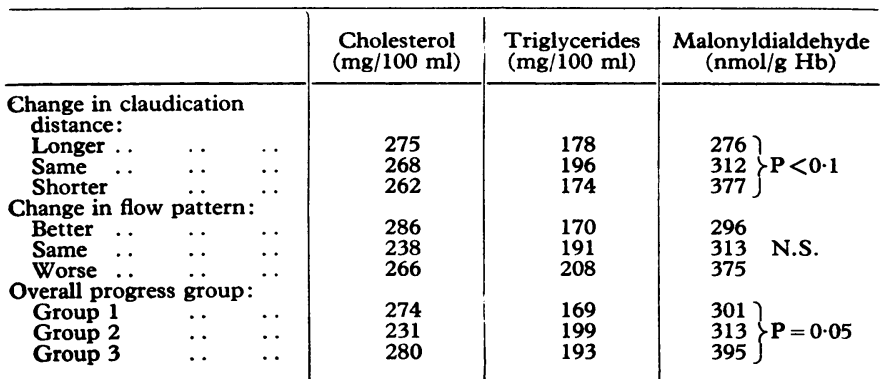

There was no statistically significant difference between any of the mean cholesterol and triglyceride values.

\section{Discussion}

Though there is wide agreement that peripheral arterial disease is rarely a cause of death and that intermittent claudication tends to improve (Singer and Rob, 1960; Begg and Richards, 1962; Taylor and Calo, 1962; Schatz, 1967), previously reported series give no indication about the presenting features which, in an important minority, point to a progressively downhill course. Even the two clinical clues suggested in the literature-a history of acute rather than gradual onset (Bloor, 1961) and the presence of diabetes (Dry and Hines, 1941; Schadt et al., 1961) -have had no prognostic value in our smaller series. The only biochemical factor which has been studied in the past in relation to outlook has been the serum cholesterol (Juergens et al., 1960), and this has proved to be totally unrelated to the progress of the leg symptoms. There has been a similar lack of correlation in our own series between progress and other serum lipid and lipoprotein measurements. In contrast to these negative findings the initial blood viscosity, the initial plasma fibrinogen, and to a less extent the initial red cell lipid findings correlated significantly with the subsequent clinical course.

Since plasma fibrinogen is a critical factor which determines whole-blood viscosity, it is likely that the effect of a raised fibrinogen on blood flow and on the course of the claudication is indirect. Whether or not this is so, the downhill course in a proportion of patients appears to be essentially a function of the rheological properties of blood. The prognostic significance of a raised red cell malonyldialdehyde is less easy to interpret; but a number of possible explanations can be envisaged. Firstly, it is possible that depletion of the red cells of polyunsaturated fatty acids (the source of malonyldialdehyde) may alter the physical character of the cells sufficiently to affect their internal viscosity or "deformability." (It may be recalled that the number of double bonds in a mixture of long-chain fatty acids is one of the variables which determines the melting point or "liquidity" of the material.) This in turn could influence the viscosity of whole blood. Secondly, the raised red cell malonyldialdehyde could reflect a more fundamental change in cell lipids which might be related to the severity of the underlying degenerative arterial disease. Though serum lipid measurements as currently performed have been shown to be of little or no value in assessing the severity and outlook of arterial degeneration in individual patients, it is possible that changes in red cell lipids reflect this process more accurately. Thirdly, if an increased red cell malonyldialdehyde reflects an increased susceptibility to lipid autoxidation in other tissues, one must consider the possible "pharmacological" effects of the secondary products of autoxidation both on blood vessels and on the causation of the pain itself.

\section{References}

Begg, T. B., and Richards, R. L. (1962). Scottish Medical fournal, 7, 341.

Bloor, K. (1961). Annals of the Royal College of Surgeons, 28, 36.

Cooley, J., and Dormandy, J. A. (1973). To be published.

Dormandy, T. L. (1971). British fournal of Haematology, 20, 457.

Dormandy, J. A., Hoare, E., Colley, J., Arrowsmith, D. E., and Dormandy, $T$. L. (1973). British Medical Yournal, 4, 581.

Dry, T. J., and Hines, E. A. (1941). Annals of Internal Medicine, 14, 1893. Fredrickson, D. S., Levi, R. I., and Lees, R. S. (1967). New England fournal of Medicine, 276, 34,94, 148.

Juergens, T. L., Barker, N. W., and Hines, E. A. (1960). Circulation, 21, 188. Schadt, D. C., Hines, E. A., Juergens, J. L., and Baker, N. W. (1961). fournal of the American Medical Association, 175, 937.

Schatz, I. T. (1967). In Atherosclerotic Vascular Disease, ed. A. N. Brest and J. H. Moyer. New York, Appleton.

Singer, A., and Rob, C. (1960). British Medical fournal, 2, 633.
Stocks, J., Modell, C. B., Offerman, E. L., and Dormandy, T. L. (1972). British fournal of Haematology, 23, 713 .

Taylor, G. W., and Calo, A. R. (1962). British Medical fournal, 1, 507. 